\title{
Trend Of Earnings Quality Under IFRS Era: In Case Of Korea
}

\author{
Jaegyung Jung, Ph.D., Tongmyong University, South Korea
}

\begin{abstract}
Korea has decided to adopt International Financial Reporting Standards (IFRS) since 2011 in order to enhance quality of financial accounting information. However, there are certain issues that fair value accounting of IFRS may deteriorate earnings quality. I investigate whether the proxies of earning qual ity used in Francis et al. (2004) such as persistence, predictability, accrual quality, and smoothness are influenced after the adoption of IFRS in Korea. I find that the trend of persistence and predictability quality shows decreasing patterns over time, suggesting that the deterioration of consistency with local GAAP may have a negative impact on the proxies of earnings quality. However, the difference of earnings quality between in post-IFRS era and pre-IFRS is not significant. In other words, trend of earnings quality after the adoption of IFRS is improved. My results mean that the trend of earnings quality in Korea shows V-shaped line, indicating that IFRS is well established and successful accounting standards in Korean capital market.
\end{abstract}

Keywords: IFRS; Earnings Quality; Trend Of Earnings Quality

\section{INTRODUCTION}

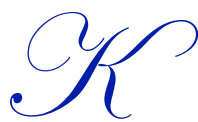

orea has adopted International Financial Reporting Standards (IFRS) since 2011. There was view on that many problems, such as corporate governance, furthermore previous Korean local GAAP per se, deteriorating earnings quality in Korea brought about the financial crisis in 1997. Korea has adopted various accounting reform enhancement plans since the financial crisis to enhance quality of financial accounting information and transparency of capital market. In particular, the adoption of IFRS from local GAAP is a remarkable change of accounting practices in Korea. IFRS is principle-based accounting standards, while Korean GAAP is rule-based ones. The principle-based accounting of IFRS can give discretion to manager by reflecting firm's substance. IFRS can also estimate assets or liabilities by fair value. In addition, IFRS demand to report fairvalue measurement method and manager's discretion contents in detail at footnotes on the financial state ment.

With the adoption of IFRS, earnings quality can draw keen attention from information user as well as manager, because there are certain issues that fair value accounting of IFRS may deteriorate earnings quality. IFRS use fair value accounting approach, while Korean local GAAP use historical cost approach in measuring earnings. It is also argued that the change of consistency from local GAAP to IFRS may have a negative impact on earnings quality. In this regard, I examine whether the trend of earnings quality is changed in revising accounting standards.

I investigate whether the proxies of earnings quality used in Francis et al. (2004) such as persistence, predictability, accrual quality, and smoothness are influenced after the adoption of IFRS in Korea. Sample consists of 3,276 nonbanking firm-years listed on Korea Exchange over 2007-2014.

My results are summarized as follows. First, for the entire sample period, the trend of persistence and predictability shows decreasing patterns over time. In other words, I find that the proxies of earnings quality in post-IFRS era mainly get worse than pre-IFRS era, suggesting that the deterioration of consistency with local GAAP may have a negative impact on earnings quality. Second, the difference of earnings quality between in post-IFRS era and preIFRS is not significant. In further analysis, after the adoption of IFRS, the overall trend of earnings quality measures except persistence shows increasing patterns significantly. This result suggests that IFRS reforms ameliorate the quality of accounting-based information. 
Increasing pattern for the IFRS period. Taken together, the trend of earnings quality in Korea shows V-shaped line after the adoption of IFRS, indicating that IFRS have settle in successful accounting standards.

Most prior studies about the adoption of IFRS in Korea show deterioration of earnings quality, whereas my results do not. This difference is because they just use initial samples of introduction of IFRS. I shed light on whether IFRS have a positive or negative impact on the earnings quality in Korea. My results provide an implication on future direction of revising accounting standards related to earnings quality for standard setters, regulators and information users.

This study is composed as follows. Section II describes the related IFRS literature and sets up the hypotheses. Section III presents methodologies to verify the hypotheses. Section IV provides the empirical results, and Section V presents conclusions.

\section{PRIOR STUDIES AND HYPOTHESES}

\subsection{Literature Review on Prior Studies}

Many of papers attempt to examine the effects of IFRS adoption. These papers are classified as factors for voluntary adopting IFRS, benefits of adopting IFRS, information contents of income under IFRS. The relation between IFRS adoption and proxies of accounting quality such as value relevance, timely loss recognition and conservatis mis well established in prior studies. For example, Bartov et al. (2005) compare the value relevance of German GAAP, IAS and US GAAP by examining companies traded on German stock market. They find return on earnings under IAS and US GAAP is more value relevant than German GAAP earnings, but no significant difference between IAS and US GAAP. Hung and Subramanyam (2007) investigate value relevance by regressing stock prices on book value and net incomes. They find that book value of equity has a higher coefficient under IAS but net incomes have a lower coefficient under IAS. This is weak evidence that accounting quality under IAS is higher than German GAAP.

It is conceptually perceived that IFRS improve the proxies of accounting quality. However, there are debate about relative benefits of accrual quality under IFRS era, and a large number of prior literatures that verify conflicting effects of IFRS adoption in terms of accrual quality. That is, some research document accounting quality improvements of voluntary IFRS adoption, but there are some papers that find no evidence of favorable effect of IFRS.

Gassen and Sellhorn (2006) select similar measure of accounting quality and suggest that German firms adopting IFRS early show more persistent, less predictable and more conditionally conservative earnings. Also, IFRS reduces information asymmetry. This results that the earnings of IFRS firms are of higher quality are similar Bartov et al. (2005).

Daske and Gebhardt (2006) investigate firms which had voluntarily adopted IFRS or US GAAP and find the quality of financial reporting has increased considerably after adoption of international standards. Daske et al. (2008) show that voluntary IFRS adopters are as sociated with an increase of market liquidity and a decline of the cost of capital and confirm consistent conclusion that IFRS reduces the information asymmetry of the investors.

Barth et al. (2008) observe improvements of accounting quality around voluntary IFRS adoption. Specifically, Firms adopting IFRS decrease earnings smoothing, and decrease managing small positive earnings towards target, and increase timely loss recognition, value relevance. Christensen et al. (2008) examine a decrease in earnings management and an increase in timely loss recognition after voluntary IFRS adoption, but mandatory adopters show no significant improvement of earnings quality.

Horton et al. (2013) examine forecast accuracy to test IFRS adoption provide higher quality information, or IFRS gives managers greater opportunities to manipulate their earnings to meet analysts' forecasts. They find that forecast accuracy and other measures of the quality of the information environment significantly increase under mandatory IFRS adoption, relative to non-adopters and voluntary adopters. 
Christensen et al. (2015) also use three measures of accounting quality such as earnings management, timely loss recognition, and value relevance. Consistent with prior literature, they find a decrease in earnings management and an increase in timely loss recognition, value relevance under voluntary adoption. In contrast, there is no accounting improvement for companies that resist IFRS adoption until 2005. These results mean reporting incentive to comply IFRS affect improvement of accounting quality.

However, there are researches that find no evidence that Voluntary IFRS adoption improve accounting quality. Van Tendeloo and Vanstraelen (2005) examine whether German companies that adopt IFRS engage in lower earnings management. During 1999 2000, IFRS adopters have more discretionary accruals compared to firms reporting under German GAAP and show lower correlation between accruals and cash flows. These results are att ributable to characteristics code-law German country and adoption of IFRS is effective in countries with strong investor protection rights.

Jamal et al. (2008) suggest that there is no clear conclusion that financial statements using U.S. GAAP are better than that using IFRS, and recommend that SEC allow companies to select between U.S. GAAP and IFRS rather than mandating of IFRS.

Callao and Jarne (2010) focus on earnings management of firms listing on 11 EU stock market and examine whether the adoption of IFRS has increased or decreased discretionary accounting practices by comparing discretionary accruals in the periods around IFRS adoption. The results show that discretionary accruals are increased in the period following implementation of IFRS. These results that earnings management is intensified after the adoption of IFRS suggest that IFRS encourage discretion of executives and opportunistic behavior.

Atwood et al. (2011) compare firms reporting under IFRS and to two control group such as firms reporting under U.S. GAAP and non-U.S. companies reporting under their domestic accounting principles. There is no significant difference in earnings persistence under IFRS versus under U.S. GAAP or under their domestic accounting principles.

\subsection{Hypothesis Development}

Prior literatures confirm IFRS enhance accounting transparency and decrease information asymmetry between insiders and outsiders by conferring on them rights to examine inside information due to the higher level of disclosure (Barth et al. 2008; Christensen et al. 2008; Horton et al. 2013). These arguments lead to the prediction that earnings quality increases in Korea.

On the other hand, prior studies suggest that discretions granted in IFRS may give manager an incentive for maximizing their utilities (Francis and Wang 2008; Ball 2009). Furthermore, earnings quality right after IFRS adoption cannot be ameliorated due to the change of consistency in accounting stand ards from local GAAP to IFRS. As a result, because there are two competing studies on the association between the adoption of IFRS and earnings quality, I set up first testable hypothes is in null form:

Hypothesis 1: Earnings quality after IFRS adoption is not different that of local GAAP era, all else being equal.

Meanwhile, earnings quality right after IFRS adoption cannot be enhanced because of the sudden change of accounting standards. However, IFRS per se can give investors more faithful information and decrease agency costs between managers and shareholders by disclosing fair value information and copious footnotes comparing to Korean local GAAP (Christensen et al. 2008; Christensen et al. 2015). That is, earnings quality can be gradually increased if IFRS is well established in Korean capital market. To sum it up, I set up hypothes is 2 as follows.

Hypothesis 2: The trend of earnings quality after IFRS adoption is increased, all else being equal. 


\subsection{Multivariate Model}

\section{RESEARCH DESIGN}

To test hypotheses, I estimate the following regression model.

$$
\begin{aligned}
& E Q_{i t}=\beta_{0}+\beta_{1} \text { TREND }_{i t}+\beta_{2} \sigma\left(S A L E S_{i t}\right)+\beta_{3} G R O W T H_{i t}+\beta_{4} S I Z E_{i t}+\beta_{5} M V_{i t} \\
& +\beta_{6} \text { OCYCLE } E_{i t}+\beta_{7} L_{\text {LOSS }}+\varepsilon_{i t}
\end{aligned}
$$

$E Q_{i t}$ : proxies of each earnings quality for firm $i$ in year $t$, see the appendix at the end of paper.

TREND: the sample year.

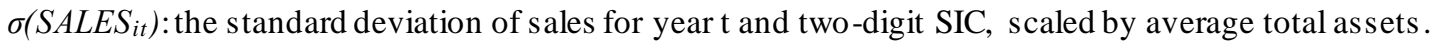

GROWTH $H_{i t}$ growth rate of sales for firm $i$ in year $t$.

$S I Z E_{i t}$ : natural logarithm of total assets for firm $i$ in year $t$

$M V_{i t}: \log$ of equity market value at the end of March in year $t+1$.

OCYCLE $E_{i t}$ : operating cycle for year $t$, measured as the sum of days' accounts receivable outstanding and days inventory held.

$\operatorname{LOSS}_{i t}: 1$ if firm i's net income is negative and 0 otherwise.

My model is similar to Francis et al. (2004) and Gaio (2010) by focusing on kinds of earnings quality. My model expects, if the increasing trend of earnings quality around post-IFRS era will be higher than pre-IFRS era, the coefficient of $\beta_{1}$ is expected to be positive (+).

I include in control variables for the innate determinants of earnings quality such as sales variability $(\sigma(S A L E S))$, operating cycle (OCYCLE), market value of equity $(M V)$, and incidence of negative earnings realizations (LOSS) shown by prior studies (Dechow and Dichev 2002; Francis et al. 2004). Meanwhile, the size of firm's total assets (SIZE) and the growth rate of total sales (GROWTH), all of which are considered to have an impact on the proxies of earnings quality, are also included in this model as control variables (Watts and Zimmerman 1986; Dechow and Dichev 2002; Francis et al. 2004).

The difference between Hypothes is 1 and Hypothesis 2 is just sample period. Hypothesis 1 includes total period, that is, pre- and post-period of IFRS adoption. Hypothesis 2 just reflect post-period of IFRS introduction.

\subsection{Proxies of Earnings Quality}

\subsubsection{Persistence and Predictability (PER/PRED)}

Sustainable relation between lagged earnings and current earnings is desirable because of their recurring (Lev 1983; Ali and Zarowin 1992; Penman and Zhang 2002). For the measurement of earnings persistence, I use the slope coefficient $\left(a_{2}\right)$ of equation (2) that is a regression model of current earnings on lagged earnings. I also meas ure earnings predictability as the negative of the standard deviation of the residual $\left(e_{t}\right)$ from equation (2) by following Lipe (1990).

$$
E_{t+1}=a_{1}+a_{2} E_{t}+e_{t}
$$

where $i, t$ are firm and year, respectively. 
$E_{t}$ : income before extraordinary items for year $\mathrm{t}$, scaled by average total assets.

$P E R_{t}$ : earnings persistence for year $\mathrm{t}$, measured as the coefficient estimate $\left(a_{2}\right)$ from cross-sectional regressions of $E_{t+1}=a_{1}+a_{2} E_{t}+e_{t}$ that are estimated by year and two-digit SIC.

$P R E D_{t}$ : earnings predictability for year $\mathrm{t}$, measured as the negative of the standard deviation of the residual $\left(e_{t}\right)$ from cross-sectional regressions of $E_{t+1}=a_{1}+a_{2} E_{t}+e_{t}$ that are estimated by year and two-digit SIC.

\subsubsection{Accrual Quality (AQ)}

Most popular proxies of accrual quality is the model proposed by Dechow and Dichev (2002), which is to capture relation between current accruals and last/ current/ next period cash flows.

Details of Dechow and Dichev (2002) equation are as follows:

$$
A C C_{t}=b_{0}+b_{1} C F_{t-1}+b_{2} C F_{t}+b_{3} C F_{t+1}+e_{t}
$$

where $i, t$ are firm and year, respectively.

$A C C_{t}$ : total accruals, computed as the change in current assets other than cash minus the change in current liabilities other than current maturities of long-term liabilities and income taxes payable minus depreciation and amortization expenses for year $\mathrm{t}$, scaled by average total assets.

$C F_{t}$ : operating cash flow for year $t$, scaled by average total as sets.

$e_{\mathrm{t}}:$ the residual of equation 3 .

$A Q_{t}$ : accrual quality for year $t$, measured as the negative of standard deviation of the residual $\left(e_{t}\right)$ from crosssectional regressions of $A C C_{t}=b_{0}+b_{1} C F_{t-1}+b_{2} C F_{t}+b_{3} C F_{t+1}+e_{t}$ that are estimated by year and two-digit SIC.

I also measure accrual quality as the negative of the standard deviation of the residual $\left(e_{t}\right)$ from equation 3.

\subsubsection{Smoothness $(S M)$}

Managers are inclined to decrease earnings volatility by smoothing out transitory fluctuations because investors prefer predictability of firm's performance (Ronen and Sadan 1981; Chaney and Lewis 1995; Demski 1998). I define smoothness as the ratio of standard deviation of income to that of cash flow (Leuz et al. 2003).

$$
S M_{t}=-\sigma\left(E_{t}\right) / \sigma\left(C F_{t}\right)
$$

where $i, t$ are firm and year, respectively.

$E_{t}$ : income before extraordinary items for year $t$, scaled by average total assets.

$C F_{t}$ : operating cash flow for year $t$, scaled by average total as sets.

$e_{\mathrm{t}}$ : the residual

\subsection{Sample Selection}

Korea has two stock markets, KOSPI and KOSDAQ. The latter is similar to NASDAQ, which is mainly composed of growth companies such as computer, R\&D or venture companies, while the former consists of large-scale firms. I collect financial information and stockprices of the listed companies from KIS (Korea Information Service). 
I use non-financial firms traded over KOSPI for 2007-2014, that is, I exclude firms in the financial industry, yearend not ending December, and issues for administration for the purpose of maintaining homogeneity of samples. I also remove firms with missing data for earnings quality measures. I winsorize all variables at the $1^{\text {st }}$ and $99^{\text {th }}$ percentile value to exclude the effect of outliers. My sample period is divided into pre-IFRS (2007 2010) and postIFRS (2011 2014) era because Korea has adopted IFRS since 2011. The number of the total samples is 3,276 firmyear observations. The process of sample selection is summarized in Table 1.

Table 1. Sample selection and distribution over years and industries

\begin{tabular}{l|c}
\hline \multicolumn{1}{c}{ Sample selection criteria } & Firm-years \\
\hline Firms traded over Korea Exchange for 2007-2014 & 4,240 \\
\hline Delete banking firms and non-December fiscal years & $(192)$ \\
\hline Delete firms with missing data for earnings quality measures & $(629)$ \\
\hline $\begin{array}{l}\text { Delete firm-y ears less than eight in each year and each two-digit industry and outliers ly ing outside top } \\
\text { and bottom one percentile of earnings quality measures }\end{array}$ & $(143)$ \\
\hline Final sample & 3,276 \\
\hline
\end{tabular}

\subsection{Descriptive Statistics}

\section{RESULTS}

Table 2 presents descriptive statistics for all variables that represent my samples by the entire time periods of 20072014 in regression model. The mean (median) of earnings persistence $(P E R)$ and predictability (PRED) are $0.549(0.565)$ and $-0.065(-0.054)$, respectively. The mean (median) of accrual quality $(A Q)$ and smoothness $(S M)$ are-0.054(-0.047) and $-0.772(-0.710)$, respectively. In general, my results are consistent with prior literatures of earnings quality in Korea.

The average size of assets (SIZE) (26.729) is higher than market value of equity $(M V)$ (25.794). The mean (median) of sales variability $(\sigma(S A L E S))$, the growth rate of total sales $(G R O W T H)$, operating cycle (OCYCLE) are 0.487 (0.456), 0.100 (0.074), and 4.789 (4.325), respectively. The incidence of negative earnings realizations (LOSS) in listed companies is 0.219 .

Table 2 reports Summary statistics.

Table 2. Descriptive statistics

\begin{tabular}{|c|c|c|c|c|c|}
\hline Variables & Mean & StdDev. & $1 \%$ & Median & $99 \%$ \\
\hline$\overline{P E R_{t}}$ & 0.549 & 0.444 & 1.425 & 0.565 & -0.520 \\
\hline$P R E D_{t}$ & -0.065 & 0.042 & -0.012 & -0.054 & -0.237 \\
\hline$A Q_{t}$ & -0.054 & 0.029 & -0.011 & -0.047 & -0.211 \\
\hline$S M_{t}$ & -0.772 & 0.314 & -0.179 & -0.710 & -2.138 \\
\hline$\sigma\left(S A L E S_{t}\right)$ & 0.487 & 0.272 & 1.978 & 0.456 & 0.149 \\
\hline$G R O W T H_{t}$ & 0.100 & 0.204 & 1.419 & 0.074 & -0.322 \\
\hline$S I Z E_{t}$ & 26.729 & 0.582 & 29.209 & 26.613 & 25.784 \\
\hline$M V_{t}$ & 25.794 & 0.626 & 28.805 & 25.824 & 24.680 \\
\hline$O C Y C L E_{t}$ & 4.789 & 1.877 & 10.596 & 4.325 & 2.124 \\
\hline$L_{O S S_{t}}$ & 0.219 & 0.414 & 1.000 & 0.000 & 0.000 \\
\hline
\end{tabular}

The sample consists of 3,276 non-banking firm-years that are traded over Korea Exchange for 2007-2014 with non-missing data that are use d in empirical analysis and collected from KIS-Value database.

See appendix for variable definitions.

\subsection{Correlation}

Pears on correlation coefficients are provided in table 3 . This table suggests that all variables of earning s quality are significantly correlated; the correlation coefficient between persistence $(P E R)$ and predictability $(P R E D)$ is 0.147 . Accrual quality $(A Q)$ exhibits highly significant correlations with predictability $(P R E D)$ and smoothness $(S M)$ at the $1 \%$ level. What is noticeable is relation between SIZE and MV, which is 0.724 . This result indicates that larger firms are more likely to have larger market value of equity. I also find negatively significant correlation between sales Copyright by author(s); $\underline{\text { CC-B Y }}$ 
variability $\left(\sigma\left(S A L E S_{t}\right)\right)$ and proxies of earnings quality. This result indicates that sales variability decrease earnings quality. Firm's size is negatively significant firm's growth and operating cycle.

Table 3 reports Pears on Correlation coefficients for variables used in the regression models.

Table 3. Pearson correlations

\begin{tabular}{|c|c|c|c|c|c|c|c|c|c|}
\hline Variables & PER $_{t}$ & PRED $_{t}$ & $\overline{\mathbf{A Q t}}$ & SMt & $\sigma\left(\right.$ S ALES $\left._{t}\right)$ & GROWTH $_{\mathrm{t}}$ & SIZE $_{t}$ & $\mathbf{M V}_{\mathrm{t}}$ & OCYCLE $_{t}$ \\
\hline$P R E D_{t}$ & 0.147 & & & & & & & & \\
\hline$A Q_{t}$ & 0.359 & 0.499 & & & & & & & \\
\hline$S M_{t}$ & 0.233 & 0.229 & 0.655 & & & & & & \\
\hline$\sigma\left(S A L E S_{t}\right)$ & -0.039 & -0.314 & -0.418 & -0.252 & & & & & \\
\hline GROWTH & -0.194 & 0.110 & -0.060 & -0.033 & 0.118 & & & & \\
\hline$S I Z E_{t}$ & -0.006 & 0.138 & 0.145 & 0.206 & -0.303 & -0.077 & & & \\
\hline$M V_{t}$ & 0.042 & 0.242 & 0.260 & 0.164 & -0.223 & -0.009 & 0.724 & & \\
\hline$O C Y C L E_{t}$ & 0.069 & -0.075 & 0.004 & -0.015 & -0.166 & 0.030 & -0.343 & -0.178 & \\
\hline$L_{O S S_{t}}$ & -0.030 & -0.160 & -0.137 & -0.106 & 0.031 & -0.065 & -0.024 & -0.107 & -0.014 \\
\hline
\end{tabular}

Correlations in italics are significant at less than $5 \%$ levels.

The sample consists of 3,276 non-banking firm-years that are traded over Korea Exchange for 2007-2014 with non-missing data that are use d in empirical analysis and collected from KIS-Value dat abase.

See appendix for variable definitions.

\subsection{Multivariate Results}

\subsubsection{Effect of IFRS on Earnings Quality}

Table 4 presents the multivariate results of empirical predictions. I present four model, which I obtain by alternating dependent variables of earnings quality proxies. Overall results on Table 4 show that the trend of persistence (PER) and predictability $(P R E D)$ decreases significantly, but that the coefficient of trend is not significant, where dependent variables are both accrual quality $(A Q)$ and smoothness $(S M)$. In other words, my results reveal that the trend of the proxies of earnings quality in post-IFRS era mainly get worse than pre-IFRS era, suggesting that the deterioration of consistency with local GAAP may have a negative impact on earnings quality.

Table 4 reports multivariate test in the regression models.

Table 4. Trend of earnings persistence, predictability and accrual quality, income smoothness over time $E Q_{i t}=\beta_{0}+\beta_{1} T R E N D_{i t}+\beta_{2} \sigma\left(S A L E S_{i t}\right)+\beta_{3} G R O W T H_{i t}+\beta_{4} S_{I Z E_{i t}}+\beta_{5} M V_{i t}+\beta_{6} O C Y C L E_{i t}+\beta_{7} L O S S_{i t}+\varepsilon_{i t}$

\begin{tabular}{|c|c|c|c|c|c|c|c|c|c|}
\hline \multicolumn{2}{|c|}{ Variables } & \multicolumn{2}{|c|}{ eqit $=P E R$} & \multicolumn{2}{|c|}{ eqit $=$ PRED } & \multicolumn{2}{|c|}{ eqit $=A Q$} & \multicolumn{2}{|c|}{ eqit $=S M$} \\
\hline & & Coeffs. & $\left(\mathrm{t}-\mathrm{stat}^{\mathrm{a}}\right)$ & Coeffs. & $\left(\mathrm{t}-\mathrm{stat} \mathbf{t}^{\mathrm{a}}\right)$ & Coeffs. & $\left(\right.$ t-stat $\left.{ }^{a}\right)$ & Coeffs. & $\left(\right.$ t-stat $\left.{ }^{a}\right)$ \\
\hline Intercept & $\left(\beta_{0}\right)$ & 20.716 & $(2.00)$ & 6.688 & $(7.51)$ & -0.240 & $(-0.40)$ & -8.190 & $(-1.14)$ \\
\hline TREND $_{t}$ & $\left(\beta_{1}\right)$ & -0.010 & $(-1.99)$ & -0.003 & $(-7.60)$ & 0.000 & $(0.30)$ & 0.003 & $(0.77)$ \\
\hline$\sigma\left(S A L E S_{i t}\right)$ & $\left(\beta_{2}\right)$ & -0.014 & $(-0.46)$ & -0.059 & $(-21.84)$ & -0.046 & $(-25.48)$ & -0.236 & $(-10.93)$ \\
\hline GROWTH $H_{i t}$ & $\left(\beta_{3}\right)$ & -0.463 & $(-11.78)$ & 0.020 & $(5.96)$ & -0.004 & $(-1.71)$ & -0.002 & $(-0.06)$ \\
\hline$S I Z E_{i t}$ & $\left(\beta_{4}\right)$ & -0.065 & $(-3.03)$ & -0.020 & $(-10.60)$ & -0.013 & $(-10.31)$ & 0.073 & $(4.88)$ \\
\hline$M V_{i t}$ & $\left(\beta_{5}\right)$ & 0.086 & (4.44) & 0.024 & $(14.46)$ & 0.015 & (13.12) & 0.003 & $(0.19)$ \\
\hline$O C Y C L E_{i t}$ & $\left(\beta_{6}\right)$ & 0.015 & $(3.20)$ & -0.004 & $(-10.50)$ & -0.002 & $(-5.81)$ & 0.000 & $(-0.12)$ \\
\hline $\operatorname{LOSS}_{i t}$ & $\left(\beta_{7}\right)$ & -0.032 & $(-1.72)$ & -0.011 & $(-6.72)$ & -0.007 & $(-6.41)$ & -0.073 & $(-5.70)$ \\
\hline $\operatorname{Adj} R^{2}$ & & \multicolumn{2}{|c|}{0.049} & \multicolumn{2}{|c|}{0.209} & \multicolumn{2}{|c|}{0.242} & \multicolumn{2}{|c|}{0.089} \\
\hline
\end{tabular}

The sample consists of 3,276 non-banking firm-years that are traded over Korea Exchange for 2007-2014 with non-missing dat a that are use d in empirical analysis and collected from KIS-Value database.

${ }^{a}$ T wo-tailed t-test; Coefficient in italics are significant at less than $5 \%$ levels.

See appendix for variable definitions.

Table 5 shows the results changed the trend variables (TREND) with a dummy variable called IFRS (IFRS). IFRS means as an interaction variable that defines a value of 1 for the post-IFRS era and 0 otherwise. That is, I compare the difference between earnings qualities before and after the adoption of IFRS. Except for predictability, the 
coefficient of IFRS is significantly positive. There are differences between of table 4 and table 5 that suggest that earnings qualities in post-IFRS era is higher than those of pre-IFRS era and that IFRS adoption is not necessarily just caused by the deterioration in earnings quality.

Table 5 reports multivariate test in the regression models.

Table 5. Comparisons of earnings persistence, predictability and accrual quality, income smoothness overtime $\overline{E Q_{i t}=\beta_{0}+\beta_{1} I F R S_{i t}+\beta_{2} \sigma\left(S A L E S_{i t}\right)+\beta_{3} G R O W T H_{i t}+\beta_{4} S I Z E_{i t}+\beta_{5} M V_{i t}+\beta_{6} O C Y C L E_{i t}+\beta_{7} L O S S_{i t}+\varepsilon_{i t}}$

\begin{tabular}{|c|c|c|c|c|c|c|c|c|c|}
\hline \multicolumn{2}{|c|}{ Variables } & \multicolumn{2}{|c|}{$e q_{i t}=p e r_{-} E_{t}$} & \multicolumn{2}{|c|}{ eq $_{i t}=$ pred $_{t}$} & \multicolumn{2}{|c|}{$e q_{i t}=a q_{t}$} & \multicolumn{2}{|c|}{$e q_{i t}=s m_{t}$} \\
\hline & & Coeffs. & $\left(\mathrm{t}-\mathrm{stat}^{\mathrm{a}}\right)$ & Coeffs. & $\left(\mathrm{t}-\mathrm{stat}^{\mathrm{a}}\right)$ & Coeffs. & $\left(\mathrm{t}-\mathrm{stat}^{\mathrm{a}}\right)$ & Coeffs. & $\left(\mathrm{t}-\mathrm{stat}^{\mathrm{a}}\right)$ \\
\hline Intercept & $\left(\beta_{0}\right)$ & 0.265 & $(0.62)$ & -0.101 & $(-2.74)$ & -0.055 & $(-2.24)$ & -2.661 & $(-9.02)$ \\
\hline$I F R S_{t}$ & $\left(\beta_{l}\right)$ & 0.031 & $(1.80)$ & -0.009 & $(-6.27)$ & 0.002 & (2.05) & 0.007 & (1.96) \\
\hline$\sigma\left(S A L E S_{i t}\right)$ & $\left(\beta_{2}\right)$ & 0.003 & $(0.09)$ & -0.058 & $(-21.48)$ & -0.046 & $(-25.38)$ & -0.237 & $(-11.02)$ \\
\hline $\mathrm{GROWTH}_{i t}$ & $\left(\beta_{3}\right)$ & -0.414 & $(-10.25)$ & 0.020 & (5.67) & -0.002 & $(-1.01)$ & -0.002 & $(-0.07)$ \\
\hline$S I Z E_{i t}$ & $\left(\beta_{4}\right)$ & -0.049 & $(-2.28)$ & -0.018 & $(-10.04)$ & -0.012 & $(-10.13)$ & 0.072 & $(4.85)$ \\
\hline$M V_{i t}$ & $(\beta 5)$ & 0.060 & $(3.16)$ & 0.023 & $(13.80)$ & 0.014 & (12.94) & 0.004 & $(0.32)$ \\
\hline$O C Y C L E_{i t}$ & $\left(\beta_{6}\right)$ & 0.017 & (3.63) & -0.004 & $(-10.13)$ & -0.002 & $(-5.68)$ & -0.001 & $(-0.16)$ \\
\hline$L O S S_{i t}$ & $\left(\beta_{7}\right)$ & -0.039 & $(-2.11)$ & -0.011 & $(-6.71)$ & -0.007 & $(-6.61)$ & -0.073 & $(-5.68)$ \\
\hline $\operatorname{Adj} R^{2}$ & & \multicolumn{2}{|c|}{0.048} & \multicolumn{2}{|c|}{0.204} & \multicolumn{2}{|c|}{0.243} & \multicolumn{2}{|c|}{0.089} \\
\hline
\end{tabular}

The sample consists of 3,276 non-banking firm-years that are traded over Korea Exchange for 2007-2014 with non-missing dat a that are used in empirical analysis and collected from KIS-Value database.

${ }^{a}$ Two-tailed t test; Coefficient in italics are significant at less than $5 \%$

levels.

See appendix for variable definitions.

\subsubsection{Effect of on Earnings Quality after IFRS Adoption}

Table 6 presents multivariate analysis in order to test our main hypothesis 2 . After the adoption of IFRS, the overall trend of earnings quality measures except persistence $(P E R)$ shows increasing patterns significantly. These results suggest that IFRS reforms ameliorate the quality of accounting-based information increasingly for the IFRS period. Taken together, the trend of earnings quality in Korea shows V-shaped line after the adoption of IFRS, indicating that IFRS have settle in successfulaccounting standards.

Table 6 reports multivariate test in the regression models

Table 6. Trend of earnings persistence, predictability and accrual quality, income smoothness after IFRS adoption $E Q_{i t}=\beta_{0}+\beta_{1}$ TREND $D_{i t}+\beta_{2} \sigma\left(S A L E S_{i t}\right)+\beta_{3} G R O W T H_{i t}+\beta_{4} S I Z E_{i t}+\beta_{5} M V_{i t}+\beta_{6} O C Y C L E_{i t}+\beta_{7} L O S S_{i t}+\varepsilon_{i t}$

\begin{tabular}{|c|c|c|c|c|c|c|c|c|c|}
\hline \multicolumn{2}{|c|}{ Variables } & \multicolumn{2}{|c|}{$e q_{i t}=p e r_{-} E_{t}$} & \multicolumn{2}{|c|}{ eq $_{i t}=$ pred $_{t}$} & \multicolumn{2}{|c|}{$e q_{i t}=a q_{t}$} & \multicolumn{2}{|c|}{$e q_{i t}=s m_{t}$} \\
\hline & & Coeffs. & $\left(t-s t a t^{a}\right)$ & Coeffs. & $\left(\mathrm{t}-\mathrm{stat}^{\mathrm{a}}\right)$ & Coeffs. & $\left(\mathrm{t}-\mathrm{stat}^{\mathrm{a}}\right)$ & Coeffs. & $\left(\mathrm{t}-\mathrm{stat}^{\mathrm{a}}\right)$ \\
\hline Intercept & $\left(\beta_{0}\right)$ & 58.460 & $(2.03)$ & -4.615 & $(-1.74)$ & -9.596 & $(-6.27)$ & -37.696 & $(-2.20)$ \\
\hline TREND $_{t}$ & $\left(\beta_{1}\right)$ & -0.030 & $(-2.14)$ & 0.002 & $(2.56)$ & 0.005 & (6.19) & 0.017 & $(2.02)$ \\
\hline$\sigma\left(S A L E S_{i t}\right)$ & $\left(\beta_{2}\right)$ & 0.321 & $(5.62)$ & -0.065 & $(-12.25)$ & -0.009 & $(-3.06)$ & 0.007 & $(0.19)$ \\
\hline GROWTH $H_{i t}$ & $\left(\beta_{3}\right)$ & 0.192 & $(1.41)$ & 0.160 & (12.75) & 0.062 & $(8.53)$ & -0.124 & $(-1.53)$ \\
\hline$S I Z E_{i t}$ & $\left(\beta_{4}\right)$ & 0.087 & $(2.60)$ & 0.010 & $(3.16)$ & -0.004 & $(-2.45)$ & 0.119 & $(6.02)$ \\
\hline$M V_{i t}$ & $(\beta 5)$ & 0.025 & $(0.89)$ & 0.007 & $(2.73)$ & 0.009 & (5.98) & -0.029 & $(-1.76)$ \\
\hline$O C Y C L E_{i t}$ & $\left(\beta_{6}\right)$ & 0.064 & (7.52) & -0.001 & $(-1.09)$ & 0.001 & (3.28) & -0.002 & $(-0.33)$ \\
\hline $\operatorname{LOSS}_{i t}$ & $\left(\beta_{7}\right)$ & -0.036 & $(-1.48)$ & -0.014 & $(-6.24)$ & -0.011 & $(-8.52)$ & -0.111 & $(-7.62)$ \\
\hline $\operatorname{Adj} R^{2}$ & & \multicolumn{2}{|c|}{0.061} & \multicolumn{2}{|c|}{0.262} & \multicolumn{2}{|c|}{0.157} & \multicolumn{2}{|c|}{0.081} \\
\hline
\end{tabular}

The sample consist of 3,276 non-banking firm-years that are traded over Korea Exchange for 2007-2014 with non-missing data that are used in empirical analysis and collected from KIS-Value database.

${ }^{\mathrm{a}}$ Two-tailed t test; Coefficient in italics are significant at less than $5 \%$

levels.

See appendix for variable definitions. 


\section{CONCLUS IONS}

IFRS is principle-based accounting standards, while Korean GAAP is rule-based ones. The principle-based accounting of IFRS can give discretion to manager by reflecting firm's substance. Therefore, IFRS adoption is expected to enhance financial reporting quality. In contrast, the lack of consistency enables information users to apply new financial reporting standards.

Most prior studies about the adoption of IFRS in Korea show deterioration of lack of earnings quality. However, my results show that earnings quality is more and more increased after IFRS adoption. This difference is because they just use initial samples of introduction of IFRS. That is, I use a wide range of period after IFRS adoption as compared to previous studies. My results find that earnings quality is increased after IFRS era, suggesting IFRS do a role as better accounting regulation than K-GAAP.

This study provides valuable implications about the role of IFRS on earnings quality in IFRS era. My results suggest that IFRS allow manager to reporting earnings substance by using more sufficient disclosure. This paper is the first empirical study to document positive effectiveness after the introduction of IFRS. By inspecting various proxies of earnings quality in IFRS era, this study will provide more information than prior studies about earnings quality. Also, this study is expected to help better understand and interpret directions and types of each earning quality depending on the adoption of IFRS.

\section{ACKNOWLEDGEMENT}

This Research was supported by the Tongmyong University Research Grants 2014(2014A018).

\section{AUTHOR BIOGRAPHY}

Jae Gyung Jung is an Assistant Professor of Department of Finance and Accounting at Tongmyong University, South Korea. Her research interests include international accounting standards and capital market. E-mail: jgjung0905@naver.com

\section{REFERENCES}

Ali, A., \& Zarowin, P. (1992). The role of earnings levels in annual earnings-returns studies. Journal of Accounting Research, 30, 286-296.

Atwood. T. J., Michael, S. D., Myers, J. N., \& Myers, L. A. (2011). Do earnings report under IFRS tell us more about future earnings and cash flows? Journal of Accounting and Public Policy 30(2), 103-121.

Ball, R. (2009). Market and political/regulatory perspectives on the recent accounting scandals. Journal of Accounting Research, 47(2), 277-323.

Barth, M.E., Landsman, W. R., \& Lang, M.H.(2008). International accounting standards and accounting quality. Journal of Accounting Research, 46(2), 467-498.

Bartov, E., Goldberg, S.R., \& Kim, M. (2005). Comparative value relevance among German, U.S., and International Accounting Standards A German stock market perspective. Journal of Accounting, Auditing \& Finance, 20, 95-119.

Callao, S., \& Jarne, J.I. (2010). Have IFRS affected earnings management in the European Union? Accounting In Europe, 7(2), 159-189.

Chaney, P., \& Lewis, C. (1995). Earnings management and firm valuation under asymmetric information. Journal of Corporate Finance, 1, 319-345.

Christensen, H. B., Hail, L., \& Leuz, C. (2008). Incentives or standards: What determines accounting quality changes around IFRS adoption? Working Paper, University of Chicago and University of Manchester.

Christensen, H. B., Lee, E., Walker, M., \& Zeng, C. (2015). Incentives or standards: What determines accounting quality changes around IFRS adoption? European Accounting Review, 24(1), 31-61.

Daske, H., Hail, L., Leuz, C., \& Verdi, R. S. (2008). Mandatory IFRS reporting around the world: Early evidence on the economic consequences. Journal of Accounting Research, 46(5), 1085-1142.

Daske, H., \& Gebhardt, G. (2006). International financial standards and expert's perception of disclosure quality 42, 461-497.

Dechow, P., \& Dichev, D. (2002). The quality of accruals and earnings: The role of accrual estimation errors. The Accounting Review, 77 (Supplement), 35-59. 
Demski, J. S. (1998). Performance measure manipulation. Contemporary Accounting Research, 15, 261-285.

Francis, J., \& Wang, D. (2008). The joint effect of investor protection and Big 4 audits on earnings quality around the world. Contemporary Accounting Research, 25(1), 1-39.

Francis, J., Lafond, R., Olsson, P., \& Schipper, K. (2004). Costs of equity and earnings attributes. The Accounting Review, 79(4), 967-1010.

Gaio, C. (2010). The relative importance of firm and country characteristics for earnings quality around the world. European Accounting Review, 19(4), 693-738.

Gassen, J., \& Sellhorn, T. (2006). Applying IFRS in Germany-determinants and consequences. Betriebswirtschaftliche Forschung und Praxis, 58(4), 365-386.

Horton, J., Serafeim, G.\& Serafeim, I.(2013). Does mandatory IFRS adoption improve the information environment? Contemporary Accounting Research, 30(1), 388-423.

Hung, M., \& Subramany am, K. (2007). Financial statement effects of adopting international accounting standards: the case of Germany. Review of Accounting Studies, 12(4), 623-657.

Jamal, K., G. Benston, D. Carmichael, T. Christensen, R. Colson, S. Moehrle, S., ... Watts, R. (2008). A perspective on the SEC's proposal to accept financial statements prepared in accordance with international financial reporting standards(IFRS) without reconciliation to U.S.GAAP. American Accounting Association's Financial Accounting Standards Committee. Accounting Horizons, 22(2), 241-248.

Leuz, C., Nanda, D., \& Wy socki, P. D. (2003). Earnings management and investor protection: An international comparison. Journal of Financial Economics, 69, 505-527.

Lev, B. (1983). Some economic determinants of time-series properties of earnings. Journal of Accounting and Economics, 5, 3148.

Lipe, R. (1990). The relation between stock returns and accounting earnings given alternative information. The Accounting Review, 65(1), 49-71.

Penman, S., \& Zhang, X. (2002). Accounting conservatism, the quality of earnings, and stock returns. The Accounting Review, 77(2), 237-264.

Ronen, J., \&Sadan, S. (1981). Smoothing income numbers: Objectives, means, and implications. Addison-Wesley.

Van Tendeloo, B., \& Vanstraelen, A. (2005). Earnings management under German GAAP versus IFRS. European Accounting Review, 14(1), 155-180.

Watts, R.L., \& Zimmerman, J. (1986). Positive accounting theory. Prentice Hall, Upper Saddle River, NJ. 


\section{APPENDIX. VARIABLE DEFINITIONS}

\begin{tabular}{|c|c|c|}
\hline$E_{t}$ & $=$ & income before extraordinary items for y ear $\mathrm{t}$, scaled by average total assets \\
\hline$P E R_{t}$ & $=$ & $\begin{array}{l}\text { earnings persistence for year t, measured as the coefficient estimate }\left(a_{11}\right) \text { from cross-sectional regressions } \\
\text { of } E_{t+1}=a_{10}+a_{11} E_{t}+e_{1 t} \text { that are estimated by year and two-digit SIC }\end{array}$ \\
\hline$P R E D_{t}$ & $=$ & $\begin{array}{l}\text { earnings predictability for year } \mathrm{t} \text {, measured as the negative of the standard deviation of the residual }\left(e_{t}\right) \\
\text { from cross-sectional regressions of } \\
E_{t+1}=a_{10}+a_{11} E_{t}+e_{1 t+1} \text { that are estimated by year and two-digit SIC }\end{array}$ \\
\hline$\overline{A Q_{t}}$ & $=$ & $\begin{array}{l}\text { accrual quality for year } \mathrm{t} \text {, measured as the negative of the standard deviation of the residual }\left(e_{2 t}\right) \text { from } \\
\text { Dechow and Dichev's }(2002) \text { cross-sectional regressions of } c a_{t}=a_{20}+a_{21} c f_{t-1}+a_{22} c f_{t}+a_{23} c f_{t+1}+e_{2 t} \text { that are } \\
\text { estimated by year and two-digit SIC, where } c a_{t} \text { is current accruals for year } \mathrm{t}\end{array}$ \\
\hline$S M_{t}$ & $=$ & $\begin{array}{l}\text { income smoothness for year } \mathrm{t} \text {, measured as the negative of the ratio of the standard deviation of income } \\
\text { before extraordinary items to the standard deviation of operating cash flows }\end{array}$ \\
\hline TREND $_{t}$ & $=$ & the sample year $(2007, \ldots, 2014)$ \\
\hline IFRS & $=$ & value of 1 for the post-IFRS era and 0 otherwise. \\
\hline$\sigma\left(S A L E S_{t}\right)$ & $=$ & the standard deviation of sales for year $\mathrm{t}$ and two-digit SIC, scaled by average total assets \\
\hline $\mathrm{GROWTH}_{t}$ & $=$ & the sales growth rate for y ear $\mathrm{t}$ \\
\hline$S I Z E_{t}$ & $=$ & $\log$ of total assets at the end of year $\mathrm{t}$ \\
\hline$M V_{t}$ & $=$ & $\log$ of equity market value at the end of March in year $t+1$ \\
\hline$O C Y C L E_{t}$ & $=$ & $\begin{array}{l}\text { operating cycle for year } \mathrm{t} \text {, measured as the sum of days accounts receivable outstanding and days } \\
\text { inventory held }\end{array}$ \\
\hline $\operatorname{LOSS}_{t}$ & $=$ & firm-y ear reports loss in year $\mathrm{t}$, and 0 otherwise \\
\hline
\end{tabular}




\section{NOTES}

